\title{
Types of Modality in Teacher-to-Teacher Talk of Forced Online Learning amidst Covid-19 Pandemic
}

\author{
Citra Laoli ${ }^{1, *}$ Rahmad Husein ${ }^{2}$ Anna Tambunan ${ }^{3}$
}

\author{
${ }^{1}$ Postgraduate School, Universitas Negeri Medan, Indonesia \\ 2 Postgraduate School, Universitas Negeri Medan, Indonesia \\ ${ }^{3}$ Postgraduate School, Universitas Negeri Medan, Indonesia \\ *Corresponding author. Email: citralaoli@gmail.com
}

\begin{abstract}
This research aimed at investigating the types of modality in teacher-to-teacher talk of forced online learning amidst covid-19 pandemic. This research was conducted qualitatively by applying content analysis approach. The data of this research were the words and clauses expressing modality uttered by teachers while they are discussing forced online learning. The data were collected by performing participant observation technique. The data then were analyzed through three steps of qualitative data analysis technique, namely: data condensation, data display, and drawing and verifying conclusions. Based on the data analysis conducted, it was found that both modalization (probability and usuality) and modulation (obligation and inclination) were found in teacher-to-teacher talk of forced online learning. Among these types of modality, modalization especially probability was most often used by the teachers in talking about online learning. The result of this study reflects the teachers' judgment on the implementation of online learning. Thus, the government should consider many aspects especially what teachers think in their attempt to make policies regarding the implementation of online learning in Indonesia.
\end{abstract}

Keywords: Modality, Teacher-to-Teacher Talk, Online Learning.

\section{INTRODUCTION}

COVID-19 pandemic has brought huge changes to many aspects of daily and professional life [1]. It has not only an adverse effect on health, but also affects the socio-economic activities of all countries in the world, including automobiles, electricity and energy, electronics, travel, tourism and transportation, agriculture and education [2]. This is consistent with Dhawan (2020) stating that this pandemic has also shaken the education sector and this concern may resonate in global education sector, including Indonesia [3].

Regarding the physical distance policy, Indonesian government has suspended the activities of all educational institutions from preschool to higher education institutions from March 17, 2020. Therefore, face-to-face teaching and learning process must be changed to adapt e-learning environment [4]. According to this policy, teachers teach at home by optimizing the use of information and communication technology (ICT).

Online learning itself is defined as the learning experience of using different devices (for examples: mobile phones, laptops, etc.) to access internet in synchronous or asynchronous environment. In these environments, students can learn and communicate with teachers and other students anywhere independently [5]. Online learning regardless of time zone, location and distance is not a problem. In asynchronous online learning, students can access online materials at any time, while synchronous online learning allows realtime interaction between students and teachers.

Modality is the speaker's judgment or request of the judgement of the listener on the status of what is being 
said [6]. Modality refers to likely or unlikely if it is a proposition and desirable or undesirable if it is a proposal. The role of the modality system is to explain the uncertainty region between "yes" and "no". Between the certainty of "it is" and "it isn't", there are relative probabilities of "it must be", "it will be" and "it may be". Similarly, between the definitive "do!" and "don't!" there are optional options "you must do", "you should do" and "you may do".

Halliday's modality system is composed of various grammatical subsystems, which reflect the speaker's judgment of the probability or obligation involved in what is said [7]. Halliday distinguishes modalization and modulation. Modalization refers to the scale of probability and usuality, while modulation refers to the scale of obligation and inclination [6]. Modalization is related to what is the case and modulation is related to what should be the case [8]. Modality can be realized in the form of modal operators, modal adjuncts, interpersonal metaphors, and predicator constituent.

As a matter of fact, modality is realized in teacherto-teacher talk of forced online learning. It can be seen from some of the transcripts got from the previous studies [9] [10].

The following is the teacher's utterances when he/she was talking about the reasons for not conducting online class.

"I believe the traditional method of teaching is a better method for effective teaching. It is highly impossible to conduct an online class for my subject." [9]

Based on the utterances above, modality is realized when the teacher was talking about the reasons for not conducting online class. The realization of interpersonal metaphor "I believe" indicates the realization of modalization, probability. Then, the realization of modal adjuncts "highly" and "impossible" indicate the realization of modalization, probability.

The following is the teacher's utterances when he/she was talking about the use of online learning through digital platforms.

"We had a participation that we never had in face-to-face courses." "Before, you had the benefit that you could meet the students and now you have to imagine what they look like because I can't put faces with names." [10]

Based on the utterances above, modality is realized when the teacher was talking about the use of online learning through digital platforms. The realization of modal adjunct "never" indicates the realization of modalization, usuality. Then, the realization of modal operator "could" indicates the realization of modalization, probability. The realization of modal operator "have to" indicates the realization of modulation, obligation. Then, the realization of modal operator "can't" indicates the realization of modalization, probability.

The analysis of teacher-to-teacher talk will provide the researcher with useful information about teachers' beliefs and values, their understanding of pedagogical and social aspects of teaching practice, and specific aspects of teacher-to-teacher discourse [11] especially on the discussions of forced online learning. In addition, the examination of teachers' talk serves a principal resource in getting on with their work, and at the same time reflects and constructs the teacher's identity and social relations [12].

For that reason, the researcher considers that it is important to conduct a study related to modality in teacher-to-teacher talk of forced online learning amidst covid-19 pandemic.

The objective of this study is:

1. To investigate the types of modality found in teacher-to-teacher talk of forced online learning

\section{REVIEW OF RELATED LITERATURE}

According to Halliday (2014) [6], interpersonal meaning can be analyzed in discourse via modality, which is divided into two grammatical areas: modalization and modulation.

\subsection{Modalization}

Modalization is one half of the general grammatical area of modality, a complex area of English grammar which has to do with the different ways in which a language user can intrude on her message, expressing attitudes and judgements of various kinds. When modality is used to argue about the probability or frequency of propositions, it is referred to as modalization [13].

As Halliday and Matthiessen presents, modalization involves the expression of two kinds of meanings:

a. Probability: where the speaker expresses judgements as to the likelihood or probability of something happening or being;

b. Usuality: where the speaker expresses judgements as to the frequency with which something happens or is.

\subsection{Modulation}

Modulation is a way for speakers to express their judgements or attitudes about actions and events. When we are acting on or for other people, we do not only have the dogmatic choices of do or don't do, I'll give you 
this or I won't give you this. But between these two poles of compliance and refusal we can express degrees of obligation and inclination [13]. Hence, when a clause is structured to exchange goods and services, it refers to the grammar of proposals.

a. Obligation occurs when the speakers/writers give command, suggestion, demand, and advice to the listeners or readers.

b. Inclination represents the tendency of the speakers/writers in doing something, and also the capability from his or her own feeling.

\section{RESEARCH METHOD}

This study was conducted qualitatively by applying content analysis approach. Moreover, the analysis of modality in teacher-to-teacher talk of forced online learning amidst covid-19 pandemic will be limited by applying Halliday's Systemic Functional Linguistics theory as the tool of analysis.

The data of this study will be the words and clauses expressing modality uttered by teachers while they are discussing forced online learning. The data will be taken from a week observation in teachers' office during break time. The source of data in this study will be 5 primary teachers teaching in one of the private primary schools in Medan. These 5 teachers are selected based on convenience sampling.

Participant observation technique will be performed to gather the data. It will be conducted when the researcher initiates the talk to get the participants' ideas about forced online learning. Observation sheet and voice recorder will be used as the instruments of data collection.

The data then were analyzed through three steps of qualitative data analysis technique, namely: data condensation, data display, and drawing and verifying conclusions.

\section{DATA ANALYSIS}

The words and clauses expressing modality then were analyzed to find the types of modality in teacherto-teacher talk of forced online learning amidst covid-19 pandemic.

\subsection{Modalization (Probability)}

The following is the teacher's utterances when she was talking about online learning in general.

Data 1

"Kalau kurasa sih, yah dibilang enak, ada segi enaknya juga, dan kalau gak enaknya ada juga sih memang"
"I think, online learning has both good side and bad side"

Based on the utterances above, modality is realized when the teacher was talking about online learning in general. The realization of interpersonal metaphor "I think" indicates the realization of modalization, probability. It can be concluded that based on the teacher's own experience, the teacher opines that online learning has both good side and bad side.

\subsection{Modalization (usuality)}

The following is the teacher's utterances when she was talking about the parents complaints during the online learning.

Data 7

"Iya apalagi zaman sekarang, orang tua banyak ngeluh, di online ini, yang ini lah, masalah uang sekolah lah, masalah paketnya lah, masalah handphone ya kan"

"Nowadays, during this online learning, parents often complain about the school fee, internet quota, and the cell phone"

Based on the utterances above, modality is realized when the teacher was talking about the parents' complaints during the online learning. The realization of modal adjunct "often" indicates the realization of modalization, usuality. It can be concluded that parents often complain to the teachers about the school fee, internet quota, and the cell phone during this online learning.

\subsection{Modulation (Obligation)}

The following is the teacher's utterances when she was talking about whether face-to-face learning should be implemented or not.

\section{Data 68}

"Kalau untuk pembelajaran tatap muka itu lah harus dilaksanakan"

"Face-to-face learning must be implemented"

Based on the utterances above, modality is realized when the teacher was talking about whether face-to-face learning should be implemented or not. The realization of predicator constituent "must be implemented" indicates the realization of modulation, obligation. It can be concluded that, based on the teacher's own experience, the teacher believes that face-to-face learning must be implemented. 


\subsection{Modulation (Inclination)}

The following is the teacher's utterances when she was talking about how the students take this online learning.

Data 49

"Masih bersyukur lagi anaknya tadi udah mau ibaratnya mengikuti pembelajaran online"

"Thank God, the students want to take this online learning"

Based on the utterances above, modality is realized when the teacher was talking about how the students take this online learning. The realization of predicator constituent "want" indicates the realization of modulation, inclination. It can be concluded that, based on the teacher's own experience, it's hard for the teacher to ask the students to take part in this online learning.

\section{FINDINGS}

Based on the data analysis conducted, it was found that both modalization including probability and usuality and modulation including obligation and inclination were realized in teacher-to-teacher talk of forced online learning. Among these types of modality, modalization especially probability was most often used by the teachers in talking about online learning. It indicates that the teachers tend to give their opinion about the probability of something happening in the talk of online learning.

\section{CONCLUSION}

The realization of the four types of modality, namely probability, usuality, obligation, and inclination reflects the teachers' judgment on the implementation of online learning. Thus, the government should consider many aspects especially what teachers think in their attempt to make policies regarding the implementation of online learning in Indonesia.

\section{REFERENCES}

[1] Shin, D. S. (2020). Introduction: TESOL and the COVID-19 Pandemic. TESOL Journal , 1-3.

[2] Nayak, J., M. Mishra, B. Naik, H. Swapnarekha, K. Cengiz, and V. Shanmuganathan. (2021). An Impact Study of COVID-19 on Six Different Industries: Automobile, Energy and Power, Agriculture, Education, Travel and Tourism and Consumer Electronics. Expert Systems , 1-32.

[3] Dhawan, S. (2020). Online Learning: A Panacea in the Time of COVID-19 Crisis. Journal of Educational Technology Systems , 1-18.
[4] Arribathi, A. H., Suwarto, A. M. Rosyad, M. Budiarto, D. Supriyanti, and Mulyati. (2021). An Analysis of Student Learning Anxiety during the COVID-19 Pandemic: A Study in Higher Education. The Journal of Continuing Higher Education , 1-14.

[5] Singh, V., and A. Thurman. (2019). How Many Ways Can We Define Online Learning? A Systematic Literature Review of Definitions of Online Learning (1988-2018). American Journal of Distance Education , 289-306.

[6] Halliday, M. A., and C. M. Matthiessen. (2014). Halliday's Introduction to Functional. Oxon: Routledge.

[7] Chen, W. (2016). The Discoursal Construction of the Lexicographer's Identity in a Learner's Dictionary: a Systemic Functional Perspective. International Journal of Lexicography , 1-28.

[8] Fairclough, N. (2003). Analysing Discourse: Textual Analysis for Social Research. London: Routledge.

[9] Kulal, A., and A. Nayak. (2020). A Study on Perception of Teachers and Students toward Online Classes in Dakshina Kannada and Udupi District. Asian Association of Open Universities , 285-296.

[10] Prieto, D., J. Tricio, F. Cáceres, F. Param, C. Meléndez, P. Vásquez, et al. (2021). Academics' and Students' Experiences in a Chilean Dental School during the COVID-19 Pandemic: A Qualitative Study. Eur J Dent Educ. , 1-9.

[11] Kosko, K. W., and Herbst, P. (2012). A Deeper Look at How Teachers Say What They Say: A Quantitative Modality Analysis of Teacher-toTeacher Talk. Teaching and Teacher Education, 589-598.

[12] Little, S. G., and Little, A. A. (2008). Psychology's Contributions to Classroom Management. Psychology in the Schools, 227-234.

[13] Eggins, S. (2004). An Introduction to Systemic Functional Linguistics. London: Continuum International Publishing Group. 